\title{
Comparative assessment of air pollutant emissions from brick manufacturing
}

https://doi.org/10.21698/rjeec.2020.222

Proceedings Paper

\section{VALERIU DANCIULESCU*, ELENA BUCUR, MIHAELA PETRESCU, MIHAI BRATU, ANDREEA COZEA, GHEORGHITA TANASE}

\author{
National Research and Development Institute for Industrial Ecology - ECOIND, 71-73 Drumul Podu Dambovitei \\ sector 6, 060652, Bucharest, Romania \\ *Corresponding author (e-mail): valeriu.danciulescu@incdecoind.ro
}

\begin{abstract}
In this paper, a comparison is made of the level of air pollution between two brick production lines that apply different technologies, one old and one new, and more efficient. The main pollutants emitted in the air from the baking kilns are $\mathrm{CO}, \mathrm{SO}_{2}, \mathrm{NO}_{2}, \mathrm{HCl}, \mathrm{HF}$, and dust. The monitoring of emissions was performed with a Testo 350 flue gas analyzer - the automatic method. A Paul Gothe isokinetic sampler was used to take dust, $\mathrm{HCl}$, and $\mathrm{HF}$ sampling, and the analysis was performed in the laboratory using gravimetric and spectrophotometric analytical methods. The results of the tests performed showed a reduction in the level of pollution by applying the new and BAT technologies by up to $90 \%$ for all monitored pollutants, compared to the pollution produced by old and non-re-technologized line. At the same time, energy consumption is lower per unit of product, which results in a significant decrease in production costs.
\end{abstract}

Keywords: air pollution, emissions, technological process, brick

\section{INTRODUCTION}

In the brick manufacturing industry, air pollution is due to the processes of burning fuels in the heat treatment furnaces of the bricks and the drying lines of raw (wet) products.

By applying new, high-performance production technologies, BAT decreases fuel consumption, increases productivity, and air pollution is lower compared to old manufacturing technologies.

The main gaseous components emitted into the air are $\mathrm{CO}, \mathrm{SO}_{2}, \mathrm{NO}_{2}$, and particles (derived from the combustion of fuels) $[1,2]$, as well as $\mathrm{HCl}$ and $\mathrm{HF}$ resulting from the burning of clay in the process of baking raw bricks. These pollutants, together with road traffic emissions, have an important contribution to zonal air pollution $[3,4]$.

This paper compares the level of air emissions from two brick production lines that apply different production technologies. Thus, we have a line that applies an old technology and a line that applies a production BAT technology [5-7]. The technological flow that takes place on both production lines includes the following main phases: a) preparation of the material, shaping of the products, handling of the raw products; b) drying of products, handling of dry products; c) baking of products, evacuation of products.

In Romania, Order no. 462/1993 and Law 278/2013 [8, 9] limit air emissions from technological processes. The emission limit values (ELV) for pollutants specific to this industry regulated by Order 462/1993 are presented in Table 1.

Table 1. ELV according to Order $462 / 1993$ for technological processes

\begin{tabular}{cc|cc}
\hline Pollutants & $\begin{array}{c}\text { ELV according to Order 462/1993 } \\
\left(\mathrm{mg} / \mathrm{Nm}^{3}\right)\end{array}$ & Pollutants & $\begin{array}{c}\text { ELV according to Order 462/1993 } \\
\left(\mathrm{mg} / \mathrm{Nm}^{3}\right)\end{array}$ \\
\hline $\mathrm{CO}$ & - & Dust & 50 \\
$\mathrm{NO}_{\mathrm{X}}$ & 500 & $\mathrm{HCl}$ & 30 \\
$\mathrm{SO}_{2}$ & 500 & $\mathrm{HF}$ & 5 \\
\hline
\end{tabular}

The values/intervals for the level of emissions of specific pollutants generated from technological processes are established by the reference document BAT for ceramics production, brick manufacturing sector (Table 2) [5]. 
Table 2. Emission values according to BAT

\begin{tabular}{c|c}
\hline Pollutants & Emission values according to BAT $\left(\mathrm{mg} / \mathrm{Nm}^{3}\right)^{*}$ \\
\hline $\mathrm{CO}$ & $1-1950$ (the level is dependent on the composition of the raw material) \\
$\mathrm{NO}_{\mathrm{x}}$ & $<250$ (for combustion processes taking place at temperatures below $\left.1300^{0} \mathrm{C}\right)$ \\
$\mathrm{SO}_{2}$ & $<500$ (when using raw materials with sulfur content $<0.25 \%)$ \\
Dust particles & $1-20$ (interval for drying processes, gas fuel combustion) \\
$\mathrm{HCl}$ & $1-30$ (the level depends on the composition of the raw material) \\
$\mathrm{HF}$ & $<10$ (the level depends on the composition of the raw material) \\
\hline
\end{tabular}

*The emission limit values refer to oxygen content in the flue gases of $18 \%$ (in volume), under normal conditions $273^{\circ} \mathrm{K}$ and 1 atmosphere.

\section{EXPERIMENTAL PART}

\section{Description of monitoring site}

Emission measurements were performed in June 2020 on pollutant dispersion chimneys [10], related to 2 manufacturing lines of ceramic products that produce elements for burnt clay masonry (bricks and ceramic blocks of different types and sizes).

Manufacturing line 1 (old) - with a production capacity of $200 \mathrm{t} /$ day (operation $24 \mathrm{~h} /$ day), it was put into operation in 1985 . The products are burned in a tunnel oven, with a length of $160 \mathrm{~m}$, which works with natural gas. The oven has three work areas: drying, burning, and cooling. In the combustion zone, the products are heated at $990^{\circ} \mathrm{C}$ for $2 \mathrm{~h}$, after which the temperature starts to drop. At the boundary between the drying and burning areas is the flue gas fan which discharges them into the atmosphere by means of a chimney with a diameter of $0.70 \mathrm{~m}$ and a height of $10 \mathrm{~m}$.

\section{Equipment}

Measurements of physical parameters and sampling of pollutants from emissions were performed at the two dispersion chimneys,

\section{Methods applied}

The methods applied for the analysis of pollutant concentrations $\left(\mathrm{HCl}, \mathrm{HF}, \mathrm{CO}, \mathrm{SO}_{2}\right.$, NOx, Dust) are ISO and EN [10-13]. For HCl and $\mathrm{HF}$, it was used isokinetic sampling and spectrophotometric analysis of samples (ISO 15713: 2006 and EN 1911: 2010), and for dust,

\section{RESULTS AND DISCUSSION}

Emission measurements at both lines were performed with the same equipment and the same analysis methods were applied. During the
Manufacturing line 2 (new) - with a production capacity of $400 \mathrm{t} /$ day (operation $24 \mathrm{~h} /$ day) it was put into operation in 2010. The products are baked in a tunnel oven, with a length of 140 $\mathrm{m}$, the combustion cycle lasting about 20 hours. The furnace works with natural gas, the combustion zone is the area where the products are baked in a maximum temperature range between $950-1000^{\circ} \mathrm{C}$, the combustion curve being electronically controlled according to the raw material parameters.

In the cooling area of the products, there is an installation for the recovery of hot gases and heat from the baked products, which are directed to the dryer where they are used to dry the products.

The tunnel kiln is provided with a flue gas evacuation chimney - corresponding to the combustion zone - with a diameter of $1.00 \mathrm{~m}$ and a height of $20 \mathrm{~m}$.

using the TESTO 350 XL Gas Analyzer and the Paul Gothe isokinetic sampler.

we used isokinetic sampling on a constant mass filter and gravimetric analysis (EN 132841:2017). For CO, SO2, NOx it was used the automatic method with a flue gas analyzer equipped with electrochemical cells (ISO 10396:2007).

emission monitoring, the two production lines operated under normal conditions, at the 
designed parameters. The measurement results, the hourly average, are presented in Table 3 .

Table 3. The measurement results, the hourly average, of the tunnel kiln - line 1 and $2\left(\mathrm{mg} / \mathrm{Nm}^{3}\right)$

\begin{tabular}{l|cccccc}
\hline Source & $\mathrm{CO}$ & $\mathrm{NO}_{\mathrm{x}}$ & $\mathrm{SO}_{2}$ & Dust & $\mathrm{HCl}$ & $\mathrm{HF}$ \\
\hline Dispersion chimney - Tunnel kiln - line 1 & 1756 & 305 & 190 & 45 & 29 & 8 \\
& & & & & & \\
Dispersion chimney - Tunnel kiln - line 2 & 260 & 210 & 110 & 25 & 18 & 5 \\
ELV according to BAT & $1-1950$ & 250 & 500 & $1-20$ & $1-30$ & $1-10$ \\
ELV according to Order 462/1993 & - & 500 & 500 & 50 & 30 & 5 \\
\hline
\end{tabular}

By analyzing the two sets of results compared to the two emission limits from technological processes, we observe aspects that are presented below.

For $\mathrm{CO}$, the national legislation does not impose Emission Limit Values (ELV), but the measured values are below the BAT values for both production lines.

For $\mathrm{SO}_{2}, \mathrm{HCl}$, and $\mathrm{HF}$, the ELV is similar to BAT values, and the two production lines emit these pollutants at a concentration below Romanian legislation and BAT limits.

Large differences between BAT and national ELV values are for nitrogen oxides and dust.
For $\mathrm{NO}_{\mathrm{x}}$, the BAT values are half of the ELV respectively $250 \mathrm{mg} / \mathrm{m}^{3}$ compared to 500 $\mathrm{mg} / \mathrm{m}^{3}$, and for dust, the BAT values are 20 $\mathrm{mg} / \mathrm{m}^{3}$ compared to $50 \mathrm{mg} / \mathrm{m}^{3}$ in the national legislation.

The values measured at line 1 for these pollutants $\left(\mathrm{NO}_{\mathrm{x}}\right.$ and dust) are below the ELV but exceed the BAT values, these being lower compared to the limit values in Order 462/1993. For all 6 pollutants, the concentrations inline 1 are up to $90 \%$ higher compared to line 2, being found as values near the ELV, without exceeding them (Fig. 1 and Fig. 2).
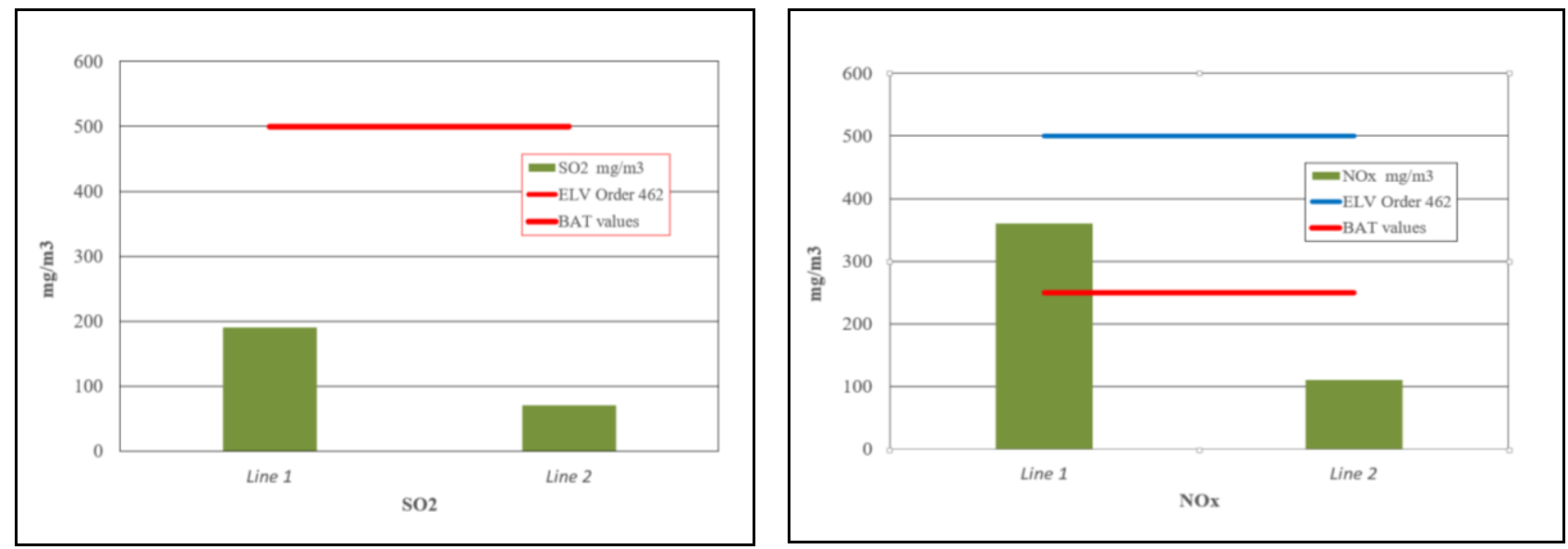

Fig. 1. The level of emission concentrations of $\mathrm{SO}_{2}$ and nitrogen oxides, in relation to ELV and BAT values
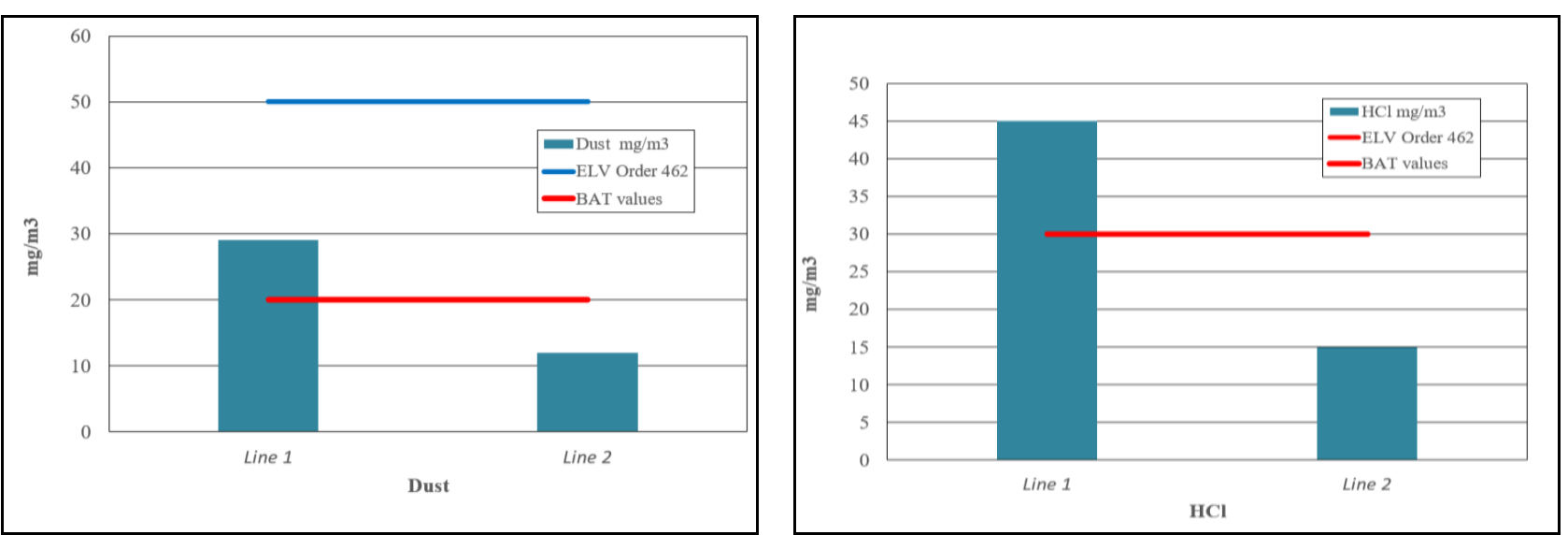

Fig. 2. The level of emission concentrations of dust and $\mathrm{HCl}$, in relation to ELV and BAT values 
The values of the low concentrations emitted by line 2 can be observed, compared to the emission limits from the national legislation and the BAT values.

Given the level of concentration values for the two pollutants, a lower combustion efficiency on line 1 is demonstrated, which leads to higher values of the pollutant concentrations. By implementing BAT technologies, more efficient burners are used, with reduced fuel consumption, resulting in lower values of nitrogen oxides, carbon monoxide, and dust.

\section{CONCLUSIONS}

Industrial pollution combined with road traffic pollution can greatly worsen air quality in an area. In addition to the measures taken to reduce pollution caused by motor vehicles, the authorities also impose measures to reduce pollution for industrial activities.

The pollution produced by the brick production activity can be reduced by applying more environmentally friendly production technologies. In this paper, a case study was performed in which the pollutant emissions in the air from two brick production plants with different technologies were compared, a new one, less polluting than the other that applies an older technology.

The gaseous components analyzed are $\mathrm{CO}, \mathrm{SO}_{2}$, $\mathrm{NO}_{2}$, dust, as well as $\mathrm{HCl}$ and $\mathrm{HF}$, these resulting from the process of baking the clay in the composition of the bricks. Comparing the two production lines, it turned out that the manufacturing line 2 is superior to line 1 in

\section{ACKNOWLEDGEMENTS}

The work was funded by Ministry of Education and Research of Romania through Programme

\section{REFERENCES}

[1] BUCUR, E., DANET, A.F., LEHR, C.B., LEHR, E., NITA-LAZAR, M., J. Air Waste Manag. Assoc., 67, no. 4, 2017, p. 391.

[2] DANCIULESCU, V., COZEA, A., PETRESCU, M., DIODIU, R., TANASE, G., VASILE, A., $21^{\text {st }}$ International Symposium "The Environment and the Industry", Bucharest, Proceedings Book, Bucharest, 2018, pp. 252.

[3] DANCIULESCU, V., BUCUR, E., PASCU, L.F., VASILE, A., BRATU, M., J. Environ.
We can conclude that to obtain low concentrations of the pollutants emitted in the air, which fall within the BAT values, it is necessary to apply new production technologies that use more efficient burners, and combustion is computer-controlled, resulting in lower pollutant emissions.

By applying BAT technology, two problems are solved at the same time, reducing by up to $90 \%$ the pollutant emissions, but also a production efficiency materialized in a lower cost per unit of product.

terms of production capacity, energy efficiency, and environmental protection.

The monitoring of emissions into the atmosphere from the emissions chimneys related to the furnaces of Lines 1 and 2, carried out in June 2020, highlighted the compliance with BAT values in terms of air pollutant emissions for all pollutants emitted from line 2 with new technology production, the technology according to BAT.

For line 1, with old technology, the level of emissions is much higher for all pollutants emitted, compared to the emissions from line 2. The level of concentrations of pollutants emitted into the air from line 1 is up to $90 \%$ higher than line 2.

Better combustion efficiency, lower heat loss, and lower emissions in the air lead to the decision to refurbish a brick factory, with remarkable results in reducing pollution and unit cost of the product.

Nucleu (PN 190402 02).

Prot. Ecol., 16, no. 3, 2015, p. 815.

[4] VASILE, A., DANCIULESCU, V., TANASE, G., KIM, L., DEDIU, V., Rev. Chim., 68, no. 8, 2017, p. 1749.

[5] Reference Document on Best Available Techniques in the Ceramic Manufacturing Industry- August 2007, https://eippcb.jrc.ec.europa.eu/sites/default/files /2019-11/cer_bref_0807.

[6] Commission Implementing Decision (EU) 2017/302 of 15 February 2017 establishing best 
available techniques (BAT) conclusions, under Directive 2010/75/EU of the European Parliament and of the Council.

[7] JRC Reference Report on Monitoring of Emissions to Air and Water from IED installations, 2017 ,

http://eippcb.jrc.ec.europa.eu/reference/.

[8] Law 278 / 2013 on Industrial Emissions, [in Romanian].

[9] Order no. 462 / 1993 for the approval of the Technical Conditions regarding the protection of the atmosphere and the Methodological Norms regarding the determination of the emissions of atmospheric pollutants produced by stationary sources, [in Romanian].
[10] ISO 15713: 2006 - Stationary source emissions - Sampling and determination of gaseous fluoride content.

[11] EN 13284-1: 2017- Stationary source emissions- Determination of low range mass concentration of dust.

[12] EN 1911: 2010 - Stationary source emissions - Determination of mass concentration of gaseous chlorides expressed as $\mathrm{HCl}$.

[13] ISO 10396: 2007 - Stationary source emissions - Sampling for the automated determination of gas emission concentrations for $\mathrm{CO}, \mathrm{SO}_{2}, \mathrm{NO}_{\mathrm{x}}, \mathrm{NO}_{2}$. 